\title{
PENERAPAN SANKSI ADAT BAGI PENYALAHGUNAAN NARKOTIKA DI DESA ADAT KESIMAN
}

\author{
Ni Made Widiari, I Wayan Rideng, Luh Putu Suryani \\ Fakultas Hukum Universitas Warmadewa, Denpasar-Bali, Indonesia \\ madewidiari22@gmail.com, wayanrideng1965@gmail.com, putusuryani099@gmail.com
}

\begin{abstract}
Abstrak
Desa ialah bagian wilayah terkecil yang diatur dalam Undang-undang. Berdasarkan PERDA Prov. Bali mengenai Desa Adat, Desa Adat merupakan kesatuan masyarakat hukum adat di Bali yang mempunyai wilayah, setiap Desa Adat dapat membuat Awig-Awig, Pararem dan Peraturan Lain. Penelitian ini mengkaji pengaturan penyalahgunaan narkotika pada pararem di Desa Adat Kesiman dan analisis penerapan sanksi adat bagi penyalahgunaan narkotika di desa adat kesiman. Penelitian ini didesain dengan penelitian empiris dengan pendeatan Perundang-undangan dan konseptual. Sumber data yaitu data primer dan sekunder yang diperoleh melalui pencatatan dan wawaancara mendalam. Hasil penelitian menunjukkan bahwa pengaturan penyalahgunaan narkotika pada para remaja desa adat kesiman diatur dalam pararem Desa Adat Kesiman Nomor: 121/01-KR/lV/2019 tentang bahaya Narkoba, jika dilanggar oleh masyarakat di Desa Adat Kesiman dapat dikenakan sanksi berupa denda $100 \mathrm{~kg}$ beras. Terhadap pemerintah agar lebih menanggulangi hal-hal yang merusak generasi muda serta terhadap masyarakat agar lebih memperhatikan bahayanya menggunakan Narkotika.
\end{abstract}

Kata Kunci: Narkotika, Peraturan Desa Adat, Sanksi Adat

\begin{abstract}
The village is the smallest part of the area regulated by law. Based on PERDA Prov. Bali regarding Traditional Villages, Traditional Villages are customary law community units in Bali which have territories, each Traditional Village can make Awig-Awig, Pararem and Other Regulations. This study examines the regulation of narcotics abuse in pararem in the Kesiman Traditional Village and analyzes the application of customary sanctions for narcotics abuse in the Kesiman traditional village. This study was designed with empirical research with a legislative and conceptual approach. Sources of data are primary and secondary data obtained through recording and in-depth interviews. The results showed that the regulation of narcotics abuse in the youth of the Kesiman traditional village is regulated in the pararem of the Kesiman Traditional Village Number: 121/01-KR/lV/2019 concerning the dangers of drugs, if violated by the community in the Kesiman Traditional Village, they can be subject to sanctions in the form of a $100 \mathrm{~kg}$ of rice. Against the government to better tackle things that damage the younger generation and the community to pay more attention to the dangers of using Narcotics.
\end{abstract}

Keywords: Narcotics, Traditional Village Regulations, Customary Sanctions

\section{PENDAHULUAN}

Indonesia sangat diikat oleh aturan hukum, hal tersebut tertuang dalam UUD R1 1945 Pasal 1 ayat 3 yang menyatakan Negara Indonesia merupakan Negara hukum. Sehingga seluruh aspek kehidupan dalam bermasyarakat, berbangsa, dan bernegara harus berdasarkan pada peraturan-peraturan hukum yang terkandung dari nilai yang ada dalam Pancasila sebagai dasar kehidupan bermasyarakat guna menciptakan tatanan masyarakat yang tertib, menciptakan ketertiban dan keseimbangan. Dalam hal ini masyarakat memiliki kewenangan sebagai subjek hukum sehingga berkewajiban mendapatkan perlindungan hukum atas hak-hak yang dimilikinya.

Desa ialah bagian wilayah terkecil dibawah Pemerintah Kota/Kabupaten. Dalam sistem kemandirian wilayah, dimana desa dengan desentralisasi tidak dapat dipisahkan dengan otonomi daerah maupun desentralisasi. Bali mempunyai dua bentuk desa yaitu Desa Adat dan Desa Administratif (Dinas). Desa Adat memiliki kurang lebih 1.488 pakraman, tergabung dalam wadah yang disebut Majelis Desa Pakraman (MDP) dan Desa Administratif (Dinas) terdiri dari Desa/perbekalan, dan Kelurahan. Berdasarkan Peraturan Daerah Provinsi Bali Nomor 4 tahun 2019, Desa Adat adalah kelompok masyarakat hukum adat bali yang mempunyai tradisi, Cata krama, 
kedudukan, susunan asli, hak-hak tradisional, serta ikatan tempat suci yang berisi pergaulan hidup masyarakat secara rurun menurun (kahyangan tiga atau kahyangan desa), tugas dan kewenangan serta harta mengatur dan mengurus rumah tangganya sendiri. Unsur pokok desa adat terdiri atas Parahyangan, Pawongan, dan Palernahan yang merupakan perwujudan filosofi Tri Hita Karana. Setiap Desa Adat dapat membuat Awig-Awig, Perarem, dan Peraturan Lain Desa Adat yang dibuat berdasarkam musyawarah (Putri \& Puspitasari, 2018).

Berdasarkan Ketentuan Pasal 18 Peraturan Daerah Provinsi Bali Nomor 4 tahun 2019 jenis Pararem terdiri dari Pararem Penyacah merupakan Pararem yang dibentuk untuk menjalankan AwigAwig, Pararem Pangele merupakan Pararem yang dibuat untuk mengatur hal yang belum terdapat dalam A wig-awig, dan Pararem Panepas Wicara yaitu Pararem yang digunakan untuk penyelesaian perkara Adat/wicara. Kenakalan remaja (juvenile delinquency) ialah perbuatan yang dilakukan pada usia remaja atau transisi masa anak-anak ke dewasa dengan melanggar norma, aturan, atau hukum dalam masyarakat (Raihana, 2016); (Karlina, 2020). Anak remaja ialah bagian yang memiliki status dan peran yang penting, dari kepentingan keluarga, remaja adalah generasi penerus yang siap tumbuh menjadi dewasa, sebagai pewaris dan penerus keluarga. Kenakalan pada remaja ternyata menimbulkan dampak seperti menghambat upaya generasi remaja yang berkualitas (Rahman, 2015). Oleh karena itu harus diupayakan menciptakan remaja yang berkualitas dengan mencegah timbulnya kenakalan remaja yang dapat merusak citra dan masa depan remaja itu sendiri dan bahkan citra dan masa depan bangsa (Prakoso, 2017).

Masalah penyalahgunaan narkotika di Indonesia merupakan masalah serius yang harus dicarikan jalan atau diberantas penyelesaiannya dengan segera. Banyak kasus kerugian materi dan kehilangan nyawa. Maka pihak Desa memberikan suatu peraturan yang berbentuk Pararem mengenai penyalahgunaan narkotika di kalangan warga Desa terutama di kalangan anak remaja. Sesuai Undangundang Nomor 35 Tahun 2009 tentang narkotika yaitu bertujuan sebagai obat dalam kepentingan ilmu pengetahuan, mencegah penyalahgunaan narkotika dan pemberantasan peredaran narkotika. Berdasarkan latar belakang di atas, maka Penelitian ini bertujuan untuk mengkaji pengaturan penyalahgunaan narkotika pada pararem di Desa Adat Kesiman dan analisis penerapan sanksi adat bagi penyalahgunaan narkotika di desa adat kesiman.

\section{METODE PENELITIAN}

Penelitian ini dikaji dengan penelitian hukum empiris yaitu melakukan observasi atau penelitian secara langsung ke lapangan guna mendapatkan kebenaran yang akurat dan mampu menunjukan adanya kesenjangan Antara norma dengan kenyataan (Hadjon, 1993). Sedangkan pendekatan penelitian yang digunakan adalah pendekatan sosiologi hukum yaitu suatu penelitian yang dilakukan terhadap kenyataan nyata masyarakat atau lingkungan masyarakat tujuan untuk menemukan fakta (fact finding), yang kemudian menuju pada identifikasi (problem identification) dan akhirya menuju kepada penyelesaian masalah (problem solution). Lokasi Penelitian ini dilakukan di Desa Adat Kesiman Kota Denpasar. Adapun alasan memilih lokasi tersebut dikarenakan pada Desa Adat Kesiman telah terjadi kasus Penyalahgunaan arkotika yang dilakukan oleh kalangan remaja. Bahan hukum primer diperoleh dari lapangan melalui observasi dan wawancara dengan pihak terkait (responden/informan) sedangkan data sekunder diperoleh dari sumber kedua berupa bahan hukum yaitu melalui studi kepustakaan berupa buku-buku. Adapun data sekunder yang digunakan adalah Undang-undang Nomor 35 Tahun 2009 tentang Nakotika, Peraturan Presiden Nomor 23 Tahun 2010 tentang Badan Narkotika Nasional, Instruksi Presiden Nomor 6 Tahun 2018 mengenai Rencana Aksi Nasional Pencegahan Pemberantasan Peredaran Gelas Narkotika dan Prekursor Narkotika Tahun 2018-2019, Peraturan Kepala Badan arkotika Nasional Nomor 3 Tahun 2015 tentang Organisasi dan Tata Kerja Badan Narkotika Nasional Provinsi dan Kabupaten/Kota, Perda Provinsi Bali Nomor 7 Tahun 2017, tanggal 28 Agustus 2017 Tentang Fasilitasi Pencegahan Penyalahgunaan Narkotika. Teknik Pengumpulan data yang digunakan adalah observasi dan wawancara dengan pedoman wawancara terbuka, dimana peneliti wawancara menggunakan daftar pertanyaan sebagai pedoman, meskipun tidak tertutup kemungkinan adanya masukan baru yang diperlukan dalam wawancara tersebut. Adapun penggunaan pedoman wawancara dimaksudkan untuk efektivitas dan efisiensi yang menjadi target wawancara, sehingga wawancara tersebut tidak menyimpang dari yang direncanakan. Setelah data terkumpul, selanjutnya dianalisis secara kualitatif deskriptif (Bambang, 2002). 


\section{HASIL DAN PEMBAHASAN}

\section{Pengaturan Penyalahgunaan Narkotika pada Pararem di Desa Adat Kesiman}

Penyalahgunaan Narkotika lebih banyak dialami oleh anak remaja. Pergaulan yang sekarang membuat perubahan pola pikir remaja untuk lebih dewasa yang dapat menjerumuskan dirinya ke jalan yang lebih buruk maupun yang lebih bermanfaat, masa remaja berusia antara 11 dan 19 tahun. Adapun yang mengatakan bahwa usia antara 11 dan 24 tahun, kecuali masa remaja yang rnerupakan masa peralihan dari anak ke masa dewasa, yaitu ketika manusia tidak dapat lagi dianggap sebagai anak oleh lingkungan, keluarga dan masyarakat, tetapi dari prospek pertumbuhan mereka, tidak ada tanda-tanda perkembangan mental atau psikologis, dan kematangan spiritual. Pada masa remaja, kehidupan manusia tel ah ban yak rnengalami perubahan yang sangat rnendasar, baik perubahan fisik, psikis, maupun psikologis. Biasanya, masa remaja ditandai dengan perkembangan fisik, perkembangan seksual, pemikiran kausal, emosi yang berlebihan, masalah lingkungan, dan interaksi sosial dengan kelompok. (Raza \& Sayuti, 2006).

Penyalahgunaan narkotika adalah menggunakan zat atau obat baik yang bersifat alarniah, sintetis, maupun semi sintetis tidak sesuai prosedur sehingga dapat menimbulkan efek penurunan kesadaran, halusinasi, serta daya rangsang. Pengertian Sanksi Adat adalah pencerminan kepribadian suatu bangsa. Karena perbedaannya ini adat memberikan identitas dari suatu bangsa (Manarisip, 2012). Kemajuan jaman dan teknologi ternyata tidak dapat menghilangkan adat kebiasaan dalam suatu masyarakat, akan tetapi terjadilah proses penyesuaian dengan kemauan zaman, sehingga adat itu tetap kekal dan segar. Dasar berlakunya Hukum Adat dibagi menjadi 3 yaitu, dasar filosofis, dasar sosiologis, dan dasar yuridis. Dalam masyarakat hukum adat di Bali, ada berbagai perbuatan yang dianggap sebagai delik adat. Perbuatan-perbuatan tersebut apabila diklasifikasikan dapat dibedakan:

a. Delik terhadap harta benda

b. Delik terhadap kepentingan orang banyak

c. Delik terhadap kehormatan seseorang,

d. Delik terhadap kesusilaan

Di samping itu pula sanksi-sanksi tersebut harus sudah ditinggalkan karena tidak sesuai lagi dengan nilai-nilai yang telah diakui secara universal (Widnyana \& Made, 1993). Penyalahgunaan narkotika dalam pararem Desa Adat Kesiman mengingatkan bahaya Narkoba, warga desa laki-laki, perempuan, anak-anak, dan remaja wajib mengingatkan warganya masing-rnasing, dan juga diadakan jalinan kekeluarga, warga desa atau warga banjar agar selalu melaksanakan kehidupan sesuai isi dari ajaran agama, agar bisa menemukan kehidupan ajaran hubangan ruhan dengan manusia, manusia dengan manusia, manusia dengan lingkungan diutamakan diwilayah warga atau melaksanakan kehidupan agar tidak memakai atau menjual Narkoba (Nintenin Indik Bhaya arkoba, Krama Desa lanang-istri, ageng-alit patut nitenin kula warganyane soang-soang, taler tindih ring kawentenan paiketan pasemetonan karma desa wiadin karma banjar mangda satata prasida ngamargiang kahuripan manut daging-daging sastra agama, gumanti sida manggihin kasukertan Tri Hita Karana utamanyane ring widang pawongan utawi ngamargiang kahuripan antuk nenten ngangge, rniwah ngadol narkoba). Untuk ini warga Desa Adat Kesiman harus mengikuti ajaran kebaikan hubungan tuhan dengan manusia, manusia dengan manusia, manusia dengan lingkungan karena diutamakan diwilayah warga mengenai pertemuan dihadapan warga Desa agar jauh dari bahayanya Narkoba itu, agar tidak menyimpang dari peraturan-peraturan. (Antuk punika karma Desa Pakraman Kesiman parut nincapang kasukertan Tri Hita Karana utamanyane ring widang pawongan indik pangraksa majeng ring karma desa mangdane sayan doh saking bhaya narkoba inucap antuk pararem ngele manut pawos-pawos ring sor): Dalam Perarem Desa Adat Kesiman yang telah diatur didalamnya dibuatkan Pasal-Pasal berupa :

Pasal I dan Pasal 2 peraturan dan (Pawos I Lan Pawos 2 Pamikukuh Lan Patitis),

Pasal 3 mengenai warga (Pawos 3 Krama)

Pasal 4 pengertian Narkoba (Pawos 4 Uning Indik Narkoba)

Pasal 5 ciri-ciri yang terkena Narkoba (Pawos 5 China Jatma Sane Keni Narkoba)

Pasal 6 memberitahu kepada warga agar tidak terkena bahayanya Narkoba (Pawos 6 Nintenin Krama Nenten Keni Bhaya Narkoba),

Pasal 7 Penambahan dalam Pararern (Pawos 7 Nguwah-Nguwah Pararem), dan

Pasal 8 Penutup (Pawos 8 Pamuput). 


\section{Penerapan Sanksi Adat Bagi Penyalahgunaan Narkotika di Desa Adat Kesiman}

Sanksi adat adalah suatu upaya untuk mengembalikan keseimbangan spiritual. Dengan kata lain sanksi adat tersebut merupakan usaha untuk menetralisir pelanggaran yang terjadi sebagai akibat pelanggaran adat. Jadi sanksi adat berfungsi sebagai penyeimbang untuk mengembalikan keseimbangan antara dunia lahir dan duniawi. Bentuk sanksi adat terkait dengan nilai dan rasa keadilan masyarakat yang saling bersangkutan. Peran dari sanksi adat adalah menyeimbangkan dan memulihkan keseimbangan antara dunia sekuler dan dunia kelahiran. Di Bali, sanksi adat memiliki peran yang sangat penting dalam memulihkan keseimbangan yang bergejolak. Sesuai konsep adat, tujuan saksi (pidana) adalah mengembalikan keseimbangan alam semesta, yaitu keseimbangan antara dunia kelahiran dan duniawi, guna menghadirkan rasa damai di antara rekan senegaranya. Sela in iru, hukuman harus adil, artinya hukuman tidak akan ditujukan kepada orang atau kelompok atau korban tertentu, juga tidak ditujukan kepada masyarakat, sehingga kehilangan ketimpangan.

Sanksi adat senantiasa berpedoman pada nilai-nilai dasar agama dan berupaya mewujudkan kesucian desa demi tercapainya perdamaian. Oleh karena itu pelaksanaan saksi adat senantiasa berpedoman pada pemulihan kesucian dan keamanan desa. Di Bali yaitu di Desa Pakraman, penerapan sanksi adat kini menghadapi tantangan kepatuhan.Keadaan ini masih harus dilihat, mungkin karena kurangnya pemahaman tentang makna sanksi adat atau dari segi sosiologis, adat istiadat. sanksi tidak lagi Mengikuti kesadaran hukum masyarakat.

Dalam Pararem Desa Adat Kesiman terdapat Jenis-jenis sanksi adat dalam pidana penyalahgunaan Narkotika yang diatur yaitu:

1) Krama Desa sane wantah ngangge keni pemidanda pamrayascita desa atau banjar (warga desa yang mengguna akan kena denda membersihkan desa atau banjar)

2) Krama Desa sane ngadol Ian wenten buktinyane olih krama desa sane lianan keni pemidanda pamrayascita desa/banjar Ian nunas iwang (warga desa yang menjual dan ada terbukti oleh warga desa yang lainnya kena denda membersihkan desa atau ban jar dan meminta maaf)

3) Krama Desa sane ngangge miwah ngadol keni pamidanda pamrayascita, nun as iwang Ian pamidanda jinah agengnyane $100 \mathrm{Kg}$ beras kelas satu (warga desa yang menggunakan dan menjual kena denda membersihkan, meminta maaf dan biaya denda sebesar $100 \mathrm{~kg}$ beras kelas satu)

Penerapan Sanksi Bagi Penyalahgunaan arkotika di Desa Adat Kesiman Dalam Desa Adat Kesiman telah membuat sebuah pararem yang mengenai memberi tahu mengenai bahayanya Narkoba (Nitenin lndik Bahaya Narkoba) yang dicantumkan dalam Pawos 5 pasal 5 mengenai China Jatma Sane Keni Narkoba (ciri orang yang terkena Narkoba) yaitu :

1) Nenten makayun ngajeng (tidak ingin makan)

2) Enten Makita masiram, Ian meweh masirah (tidak ingin mandi dan susah mandi)

3) Mayus nunas pekaryan, Jan angga sarirannyane tiris (tidak ingin mengambil pekerjaan dan berfikir pendek)

4) Biji batu penyingakan ngalitang sakadi jaum taler biji batu penyingakannyane lombeng (bola matanya lurus seperti jarum dan bola matanya kelihatan lebar)

5) Pepesan bogbog Ian brangti (sering berbohong dan marah)

6) Nenten sida malaksana sane gel is Ian apatis (tidak bisa bekerja cepat dan praktis)

7) Pepesan mamurug Ian mapangangge bucek (sering ngelabrak dan berpakaian kucel)

Pawos 6 pasal 6 mengenai Nitenin Krama Nenten Keni Narkoba (menginformasikan warga tidak kena tentang bahayanya Narkoba)

\section{SIMPULAN DAN SARAN}

\section{Simpulan}

Berdasarkan hasil analisis data, dapat disimpulkan bahwa penyalahgunaan narkotika akan diberi sanksi adat adalah suatu tindakan yang melanggar perasaan keadilan dan kepatutan yang hidup dalam masyarakat hingga mengakibatkan terganggunya keseimbangan serta ketentraman masyarakat. Sanksi adat yang dikenakan terhadap seseorang penyalahgunaan narkotika di Desa Adat Kesiman ialah Warga desa dikenakan denda membersihkan desa atau banjar, meminta maaf terhadap warga desa, Warga desa yang menggunakan narkotika dikenakan denda $100 \mathrm{~kg}$ beras. 


\section{Saran}

Dari simpula penelitian di atas, peneliti memberi saran bagi pemerintah agar menjalankan sanksi dan mengembangkan program-program yang sudah diterapkan bagi masyarakat yang menyalahgunakan narkotika di setiap wilayah Desa Adat. Bagi masyarakat agar dapat digunakan sebagai acuan informasi dan pengetahuan bagaimana peraturan tindakan penyalahgunaan narkotika bagi anak remaja di wilayah Desa Adat, agar tidak terjadinya pelanggaran yang membuat fatal bagi generasi muda di Indonesia. Bagi peneliti selanjutnya untuk melakukan penelitian dibidan kajian Narkotika untuk mendapatkan solusi yang tepat dalam pencegahan penyalahgunaan Narkoba

\section{DAFTAR PUSTAKA}

Bambang, W. (2002). Penelitian Hukum dalam Praktek. Jakarta: Sinar Grafika.

Hadjon, P. M. (1993). Penghantar Hukum Administrasi. University Press.

Karlina, L. (2020). Fenomena Terjadinya Kenakalan Remaja. Jurnal Edukasi Nonformal, 1(2), 147158.

Manarisip, M. (2012). Eksistensi Pidana Adat dalam Hukum Nasional. Jurnal Lex Crimen, 1(4), 24 40.

Prakoso, A. (2017). Kriminologi dan Hukum Pidana. Yogyakarta. Laksbang Pessindo.

Putri, K. A. M. P., \& Puspitasari. (2018). Pengaruh Hukum Adat atau Awig-Awig Terhadap Pengelolaan Dana Desa di Desa Banjar Kecamatan Banjar Kabupaten Buleleng Provinsi Bali. Jurnal Ilmiah Akuntansi Dan Humanika, 8(1), 1-13.

Rahman, muzdalifah M. (2015). Upaya Orang Tua dalam Membimbing Remaja. Jurnal Bimbingan Konseling Islam, 6(1), 41-62.

Raihana. (2016). Kenakalan Anak (Juvenile Deliquency) dan Upaya Penanggulangannya. Sisi Lain Realita, 1(1), 72-83.

Raza, A., \& Sayuti, W. (2006). Remaja dan Bahaya Narkoba. Jakarta. Prenada.

Widnyana, \& Made, I. (1993). Kapita Selekta Hukum Pidana Adat. Bandung. PT Eresco. 